\title{
Anti-inflammatory Potential of Macamides Isolated from Yellow Tubers of Mashua (Tropaeolum Tuberosum)
}

\section{(๑) $\odot \Theta$}

\author{
Authors \\ Luis Apaza Ticona1, 2(D, María Rodríguez Coballes ${ }^{1}$, Giulia Potente ${ }^{3}$, Ángel Rumbero Sánchez ${ }^{1}$
}

\section{Affiliations}

1 Department of Organic Chemistry, Faculty of Sciences, University Autónoma of Madrid, Madrid, Spain

2 Department of Pharmacology, Pharmacognosy and Botany, Faculty of Pharmacy, University Complutense of Madrid, Madrid, Spain

3 Department for Life Quality Studies, University of Bologna, Rimini, Italy

Key words

Tropaeolaceae, Tropaeolum tuberosum, fatty acids, macamides, antiinflammatory

$\begin{array}{ll}\text { received } & 29.01 .2020 \\ \text { revised } & 02.04 .2020 \\ \text { accepted } & 16.04 .2020\end{array}$

Bibliography

DOI https://doi.org/10.1055/a-1159-4242

Planta Med Int Open 2020; 7: e88-e99

(c) Georg Thieme Verlag KG Stuttgart · New York ISSN 2509-9264

\section{Correspondence}

Prof Dr Luis Apaza T

Department of Organic Chemistry, Faculty of Sciences,

University Autónoma of Madrid, Cantoblanco

28049 Madrid

Spain

Tel.: + 34914977622 Fax: + 34914974715

luis.apaza@uam.es; Inapaza@ucm.es

$\oplus$ Supporting Information for this article is available online at http://www.thieme-connect.de/products.

\section{ABSTRACT}

Although Tropaeolum tuberosum tubers have been consumed cooked as a folk remedy for the treatment of skin, lungs, liver and kidneys diseases, these uses have very limited scientific basis. Therefore, this article develops a phytochemical analysis of the yellow tubers of $T$. tuberosum with the objective to assess whether the isolated compounds have anti-inflammatory potential in the CCD-1109Sk, MRC-5 and RWPE- 1 cell lines. We performed an extraction of $T$. tuberosum tubers using different organic solvents, followed by a bioguided chromatographic separation. Four macamides were identified by LC/MS techniques, but only $\mathrm{N}$-benzyllinoleamide (1) and $\mathrm{N}$-benzyloleamide (2) were isolated and elucidated by NMR/MS techniques, given that they were present in a larger proportion in the tubers. The anti-inflammatory potential of macamides was evaluated by the inhibition of NF-KB and STAT3 activation. Both compounds displayed inhibition of NF-KB activation with $\mathrm{IC}_{50}$ values of $2.28 \pm 0.54 \mu \mathrm{M} ; 3.66 \pm 0.34 \mu \mathrm{M}$ and $4.48 \pm 0.29 \mu \mathrm{M}$ for compound (1) and $6.50 \pm 0.75 \mu \mathrm{M} ; 7.74 \pm 0.19 \mu \mathrm{M}$ and $8.37 \pm$ $0.09 \mu \mathrm{M}$ for compound (2) in CCD-1109Sk, MRC-5 and RWPE-1 cell lines, respectively. Moreover, both compounds inhibited the STAT3 activation with $\mathrm{IC}_{50}$ of $0.61 \pm 0.76 \mu \mathrm{M} ; 1.24 \pm 0.05 \mu \mathrm{M}$ and $2.10 \pm 0.12 \mu \mathrm{M}$ for compound (1) and $5.49 \pm 0.31 \mu \mathrm{M} ; 7.73 \pm$ $0.94 \mu \mathrm{M}$ and $7.79 \pm 0.30 \mu \mathrm{M}$ for compound (2). Therefore, isolated macamides of $T$. tuberosum tubers showed promising anti-inflammatory effects, suggesting a possible beneficial use to combat inflammatory processes of skin, lung and prostate. 


\section{ABBREVIATIONS}

$\begin{array}{ll}\text { AG 490 } & \text { (E)-2-Cyano-3-(3,4-dihydrophenyl)-N- } \\ & \text { (phenylmethyl)-2-propenamide } \\ \text { AP-1 } & \text { Activator protein 1 } \\ \text { ATCC } & \text { American Type Culture Collection } \\ \text { CB1 } & \text { Cannabinoid receptor type 1 } \\ \text { CRM1 } & \text { Chromosomal Maintenance 1 } \\ \text { DBD } & \text { DNA-binding domain } \\ \text { DMEM } & \text { Dulbecco's Modified Eagle Medium } \\ \text { DTT } & \text { Dithiothreitol } \\ \text { FAAH } & \text { Fatty acid amide hydrolase } \\ \text { FAMEs } & \text { Fatty acid methyl esters } \\ \text { FBS } & \text { Fetal bovine serum } \\ \text { HR-ESIMS } & \text { High resolution-Electrospray ionisation mass } \\ & \text { spectrometry } \\ \text { IFN-Y } & \text { Interferon gamma } \\ \text { IKB } \alpha & \text { Nuclear factor of kappa light polypeptide gene } \\ & \text { enhancer in B-cells inhibitor, alpha } \\ \text { IKK } & \text { IKB kinase } \\ \text { IL-1B } & \text { Interleukin-1 beta } \\ \text { IL-6 } & \text { Interleukin-6 } \\ \text { IL-17 } & \text { Interleukin-17 } \\ \text { L-SIMS } & \text { Liquid secondary ion mass spectrometry } \\ \text { JAK } & \text { Janus kinase } \\ \text { LDH } & \text { Lactate dehydrogenase } \\ \text { MAPK } & \text { Mitogen-activated protein kinase } \\ \text { MRM } & \text { Multiple reaction monitoring } \\ \text { NF-KB } & \text { Nuclear factor kappa B } \\ \text { PBS } & \text { Phosphate-buffered saline } \\ \text { PMS } & \text { Phenazine methosulfate } \\ \text { PUFAs } & \text { Polyunsaturated fatty acids } \\ \text { RLU } & \text { Relative light units } \\ \text { SH2 } & \text { Src Homology 2 } \\ \text { STAT3 } & \text { Signal transducer and activator of transcription 3 } \\ \text { TNF- } \alpha & \text { Tumour necrosis factor alpha } \\ \text { XTT } & \text { 2,3-Bis-(2-methoxy-4-nitro5-sulfophenyl)-2H- } \\ & \text { tetrazolium-5-carboxanilide salt } \\ & \end{array}$

\section{Introduction}

Inflammation has long been a well-known symptom of many infectious diseases, but molecular and epidemiological research increasingly suggests that it is also intimately linked with a broad range of non-infectious diseases [1]. The major steps in an inflammatory cascade are the initiation of the reaction, the progression and the termination, followed by the resolution of inflammation [2]. Infection and inflammation stimulate immune cells to produce a variety of immune mediators including pro-inflammatory cytokines such as: IL$1 \beta$, IL-6, TNF- $\alpha, N F-\kappa B$, STAT3, IFN- $\gamma$ that are crucial in the inflammation process [3].

In the case of NF- $\mathrm{kB}$, this is a dimeric transcription factor of $\mathrm{p} 50$ and $\mathrm{p} 65$ subunits, crucial regulator of many physiological and pathophysiological processes, including the control of inflammatory responses [4]. NF- $\mathrm{kB}$ relays signals from activated receptors in the plasma membrane to the nucleus, where it regulates gene expression. Canonical NF-kB activation by TNF- $\alpha$ involves phosphorylation and proteasomal elimination of $1 \kappa B \alpha$, uncovering a nuclear localisation signal of NF-kB. Consequently, NF-KB accumulates in the nucleus and regulates the expression of target genes [5].

On the other hand, there are cytokines that express themselves ubiquitously and have more pleiotropic functions, such as STAT3 [6]. Like other members of the STAT family (STAT1, STAT2, STAT4, STAT5A, STAT5B and STAT6), STAT3 signalling involves tyrosine phosphorylation by JAK or other tyrosine kinases, or the nuclear dimerization/translocation [7]. Moreover, in the nucleus, STAT3 binds to DNA and regulates the expression of the target gene. After dephosphorylation, STAT3 dissociates from DNA and leaves the nucleus through CRM1-mediated export to the cytoplasm, where it becomes available for reactivation. Aberrant STAT3 signalling has proven to be a key factor in chronic inflammation and autoimmune conditions, defining STAT3 as a promising therapeutic target [8].

Finally, we must indicate that the NF-KB and STAT3 transcription factors are ubiquitously expressed and control numerous physiological processes including the development, differentiation and immunity of the cell. Both NF-кB and STAT3 are rapidly activated in response to various stimuli including stresses and cytokines, although they are regulated by entirely different signalling mechanisms [9]. The activation of and interaction between STAT3 and NF-kB play a key role in controlling the dialogue between the inflammatory cell and its microenvironment [10].

Currently, synthetic medications such as nonsteroidal anti-inflammatory drugs and biological agents decrease acute and chronic inflammation. However, the use of such agents can cause adverse effects [11]. For this reason, alternatives such as herbal therapies may have a better risk-benefit ratio. In addition, it should be noted that the plants have several chemical components of medicinal importance that can be directed to multiple signalling pathways. It is in this context that the use of medicinal herbs is growing due to their low cost, easy availability and insignificant side effects [12].

Mashua (Tropaeolum tuberosum Ruíz \& Pavón) is an herbaceous climbing plant that belongs to the Tropaeolaceae family. It grows at altitudes between 3000 and 4000 meters in the cold temperate zones of the Andes. It produces small edible tubers of different colours, the yellow colour being the most consumed because of its anti-inflammatory properties [13]. Documentation has been found that indicates that the cultivation of this plant dates back to the pre-Inca period and currently represents a source of livelihood for the Andean populations [14].

Mashua tubers have been attributed different properties, due to their traditional use, for example their consumption is recommended in the treatment of different skin diseases [13,15]; lung diseases $[13,16]$; urinary diseases $[13,17]$; infectious diseases $[13,18]$ and as an analgesic against kidney and bladder pain $[13,16]$. To date, a large number of secondary metabolites present in T. tuberosum tubers have been identified and quantified, such as phenolic acids and tannins [19,20], flavonoids (flavonols and anthocyanins) [19,21], glucosinolates and isothiocyanates [22], fatty acids [23] and alkamides [24]. Some of these metabolites have been studied to determine if they are responsible for the medicinal properties that are attributed to these tubers. 
The objective of our work is to determine the anti-inflammatory activity (inhibition of NF-KB and STAT3 activation) of the yellow tubers of $T$. tuberosum. For this analysis we have used different cell lines, taking into account the diseases against which tubers of Mashua have been used in traditional medicine. CCD-1109Sk (skin cells), MRC-5 (lung cells) and RWPE-1 (prostate cells), and a control cell line (THP-1) cell lines were used.

\section{Results and Discussion}

CCD-1109Sk (Human skin fibroblast, CRL-2361), MRC-5 (Human lung fibroblast, CCL-171) and RWPE-1 (Human prostate epithelial, CRL-11609) cell lines were selected to carry out the in vitro cytotoxicity/viability and activity assays of the $T$. tuberosum extracts and compounds. We have selected these cell lines according to their physiological relationship with certain diseases that are treated in traditional medicine through the consumption of cooked T. tuberosum tubers [13]. Therefore, the relationship is: the MRC-5 cell line for lung diseases such as influenza and tuberculosis $[13,16,25]$, the RWPE- 1 cell line for kidney diseases such as prostatitis and stones in the bladder [13, 26, 27]. In the case of skin diseases such as eczema, ulcers, the CCD-1109Sk cell line was applied in the form of a compress [13, 28, 29]. Furthermore, a cell line (THP-1) was used to assess the safety of the compounds.

Through the LDH and XTT assays ( $\vee$ Table 1 ), we observed that the aqueous and $n$-heptane extracts of the yellow tubers of T. tuberosum did not show cytotoxicity (LDH) compared to the control (Triton X-100), in addition to being viable (XTT) in the CCD-1109Sk, MRC-5 and RWPE- 1 cell lines compared to the control (Actinomycin D). Likewise, we observed that the $\mathrm{CH}_{2} \mathrm{Cl}_{2} / \mathrm{MeOH}$ extract showed cytotoxicity (LDH) in all the cell lines we analysed, in addition to not showing viability (XTT), being discarded from the next research phase of anti-inflammatory activity assays.

To understand the results of the LDH and XTT assays, we must reflect on the action of the extracts at a specific site within the cells. There are two ways in which a cell suffers death, either by exposure to a harmful environment and/or injury (necrosis) or by a process of decomposition (apoptosis) previously planned and regulated. In our case, the LDH assay was used to measure cell necrosis [30] and the XTT assay to determine cell apoptosis [31]. Analysing the results obtained, we can indicate that the aqueous and $n$-heptane extracts did not show cytotoxicity and proved to be viable for the cell lines tested using the LDH and XTT assays, respectively. Finally, no significant differences were observed between both extracts.

With respect to anti-inflammatory activity, only the $n$-heptane extract of the yellow tubers of $T$. tuberosum showed an inhibition of NF-KB and STAT3 in all cell lines. In the case of inhibition of TNF$\alpha$-induced NF-kB activation, the $n$-heptane extract showed an $\mathrm{IC}_{50}$ of $63.00 \pm 0.03 \mu \mathrm{g} / \mathrm{mL} ; 66.03 \pm 0.72 \mu \mathrm{g} / \mathrm{mL}$ and $71.76 \pm 0.39 \mu \mathrm{g} / \mathrm{mL}$ on CCD-1109Sk, MRC-5 and RWPE-1 cells, respectively ( $\triangleright$ Table 2 ).

Likewise, in the case of inhibition of STAT3 activation induced by IFN- $\gamma$, only the $n$-heptane extract of $T$. tuberosum showed activity on the CCD-1109Sk, MRC-5 and RWPE- 1 cell lines with an IC 50 of $55.05 \pm 0.68 \mu \mathrm{g} / \mathrm{mL}, 58.48 \pm 0.38 \mu \mathrm{g} / \mathrm{mL}$ and $63.42 \pm 0.51 \mu \mathrm{g} / \mathrm{mL}$, respectively ( $\triangleright$ Table 3 ).

Observing the ${ }^{1} \mathrm{H}-\mathrm{NMR}$ spectrum of the $n$-heptane extract ( Fig. 1S), a signal at 7.34 ppm characteristic of the benzyl aromatic protons could be seen. Likewise, characteristic signals of fatty acids mixtures were observed, which were compared with the data reported [32]. These are included in $\triangleright$ Table 1S, in which the chemical shifts of the $n$-heptane extract were observed. A brief indication is also made to the type of corresponding hydrogens for each group of signals in the spectrum.

Based on the results obtained, the $n$-heptane extract was fractionated by a chromatographic column to isolate its active compounds. From the nine resulting fractions, fraction III was the most active ( $\triangleright$ Tables 4 S-5S) in all cell lines. For this reason, the respective FAMEs of fraction III ( $\triangleright$ Fig. 1) were prepared for further analysis by GC/MS. The results of the GC/MS determination of the FAMEs present in fraction III ( $\triangleright$ Fig. 1) showed that the main fatty acids were: palmitic, oleic and linoleic ( $\triangleright$ Table 4).

The results obtained corroborate the results found in the literature, which mention that the main fatty acids present in $T$. tuberosum are: palmitic (C16:0), linoleic (C18:2) and $\alpha$-linolenic (C18:3) [23]. In our work, we have identified a total of nine fatty acids in fraction III, while previous authors have reported the presence of

- Table 1 LDH and XTT assays of the extracts from T. tuberosum against a panel of human cell lines after $12 \mathrm{~h}$ of treatment.

\begin{tabular}{|c|c|c|c|c|}
\hline \multirow{2}{*}{ Samples } & \multicolumn{4}{|c|}{ \% Viable cells } \\
\hline & THP-1 & CCD-1109Sk & MRC-5 & RWPE-1 \\
\hline Untreated cells & $99.96 \pm 0.27$ & $96.95 \pm 0.50$ & $97.11 \pm 0.01$ & $97.85 \pm 0.39$ \\
\hline Triton X-100 & $10.61 \pm 0.93$ & $11.45 \pm 0.94$ & $9.38 \pm 0.57$ & $10.71 \pm 0.92$ \\
\hline$n$-Heptane extract ${ }^{a}$ & $96.78 \pm 0.42$ & $92.79 \pm 0.51$ & $93.81 \pm 0.87$ & $93.93 \pm 0.27$ \\
\hline $\mathrm{CH}_{2} \mathrm{Cl}_{2} / \mathrm{MeOH}$ extract ${ }^{\mathrm{a}}$ & $60.62 \pm 0.41$ & $62.05 \pm 1.63$ & $67.42 \pm 0.47$ & $68.07 \pm 1.76$ \\
\hline Aqueous extract ${ }^{\mathrm{a}}$ & $>100 \pm 1.16$ & $97.76 \pm 0.82$ & $97.15 \pm 0.53$ & $98.60 \pm 2.09$ \\
\hline Untreated cells & $100.01 \pm 0.28$ & $98.96 \pm 0.31$ & $99.90 \pm 0.32$ & $99.99 \pm 1.94$ \\
\hline Actinomycin D & $50.54 \pm 0.56$ & $49.73 \pm 0.58$ & $50.59 \pm 0.44$ & $47.79 \pm 0.55$ \\
\hline$n$-Heptane extract ${ }^{\mathrm{b}}$ & $98.32 \pm 0.36$ & $94.00 \pm 0.89$ & $94.19 \pm 0.02$ & $94.30 \pm 1.26$ \\
\hline $\mathrm{CH}_{2} \mathrm{Cl}_{2} / \mathrm{MeOH}$ extract ${ }^{\mathrm{b}}$ & $61.02 \pm 0.45$ & $66.33 \pm 0.43$ & $68.21 \pm 0.10$ & $68.64 \pm 0.04$ \\
\hline Aqueous extract ${ }^{b}$ & $>100 \pm 1.37$ & $98.20 \pm 0.64$ & $97.44 \pm 0.21$ & $98.73 \pm 2.34$ \\
\hline
\end{tabular}


- Table 2 Effect of the extracts from T. tuberosum on TNF- $\alpha$-induced NF-kB activation.

\begin{tabular}{|c|c|c|c|c|}
\hline \multirow{2}{*}{ Samples } & \multicolumn{4}{|l|}{$\mathrm{IC}_{50}$} \\
\hline & THP-1 & CCD-1109Sk & MRC-5 & RWPE-1 \\
\hline TNF- $\alpha 30 \mathrm{ng} / \mathrm{mL}$ & $>100 \pm 0.35$ & $97.72 \pm 0.14$ & $99.87 \pm 0.12$ & $99.93 \pm 0.07$ \\
\hline Celastrol $(7.41 \mu \mathrm{M})+$ TNF- $\alpha 30 \mathrm{ng} / \mathrm{mL}$ & $49.48 \pm 0.07$ & $47.75 \pm 0.75$ & $53.56 \pm 0.06$ & $55.59 \pm 0.57$ \\
\hline$n$-Heptane extract $(\mu \mathrm{g} / \mathrm{mL})+$ TNF- $\alpha 30 \mathrm{ng} / \mathrm{mL}$ & $72.45 \pm 0.72$ & $63.00 \pm 0.03$ & $66.03 \pm 0.72$ & $71.76 \pm 0.39$ \\
\hline Aqueous extract $(\mu \mathrm{g} / \mathrm{mL})+$ TNF- $\alpha 30 \mathrm{ng} / \mathrm{mL}$ & $97.90 \pm 0.91$ & $90.80 \pm 0.45$ & $92.84 \pm 0.90$ & $95.32 \pm 0.21$ \\
\hline \multicolumn{5}{|c|}{$\begin{array}{l}\text { Results are represented as the percentage of inhibition considering } 100 \% \text { of the value of TNF- } \alpha \text {-induced NF- } k \text { B activation and are the means }( \pm \text { SD) of } \\
\text { three separate experiments performed in triplicate. Control = untreated cells. Significant difference among means }(p<0.0001) / \text { Tukey's multiple } \\
\text { comparisons test. }\end{array}$} \\
\hline
\end{tabular}

- Table 3 Extracts of T. tuberosum inhibit IFN- $\gamma$-induced STAT3 activation.

\begin{tabular}{|c|c|c|c|c|}
\hline \multirow{2}{*}{ Samples } & \multicolumn{4}{|l|}{$\mathrm{IC}_{50}$} \\
\hline & THP-1 & CCD-1109Sk & MRC-5 & RWPE-1 \\
\hline $\mathrm{IFN}-\gamma 25 \mathrm{U} / \mathrm{mL}$ & $99.98 \pm 0.53$ & $97.20 \pm 0.67$ & $98.23 \pm 0.93$ & $99.00 \pm 0.68$ \\
\hline AG $490(48 \mu \mathrm{M})+\mathrm{IFN}-\gamma 25 \mathrm{U} / \mathrm{mL}$ & $51.20 \pm 0.57$ & $46.20 \pm 0.73$ & $47.70 \pm 0.31$ & $48.81 \pm 0.43$ \\
\hline$n$-Heptane extract $(\mu \mathrm{g} / \mathrm{mL})+\mathrm{IFN}-\gamma 25 \mathrm{U} / \mathrm{mL}$ & $60.54 \pm 0.11$ & $55.05 \pm 0.68$ & $58.48 \pm 0.38$ & $63.42 \pm 0.51$ \\
\hline Aqueous extract $(\mu \mathrm{g} / \mathrm{mL})+$ IFN- $-\gamma 25 \mathrm{U} / \mathrm{mL}$ & $96.45 \pm 0.31$ & $85.20 \pm 0.34$ & $88.12 \pm 0.79$ & $90.16 \pm 0.85$ \\
\hline \multicolumn{5}{|c|}{$\begin{array}{l}\text { Results are represented as the percentage of inhibition considering } 100 \% \text { of the value of IFN- } \gamma \text {-induced STAT3 activation and are the means }( \pm \text { SD) of } \\
\text { three separate experiments performed in triplicate. Control }=\text { untreated cells. Significant difference among means }(p<0.0001) / \text { Tukey's multiple } \\
\text { comparisons test. }\end{array}$} \\
\hline
\end{tabular}

fourteen fatty acids [23]. This difference is due to the fact that in these previous works authors used dehydrated tubers flour (six different varieties), and the esterification was made from an extract enriched in fat without additional fractionation.

Analysing the six subfractions obtained from fraction III using a chromatographic column, we observed that the sub-fraction IIID showed the highest activity ( $\triangleright$ Tables 6S-7S) in all cell lines, proceeding to analyse the sub-fraction IIID by LC/MS. - Fig. 2 shows the LC/MS chromatogram resulting from the identification of four macamides present in the sub-fraction IIID.

To identify which macamide corresponds to each MS spectrum, the fatty acids present in fraction III (myristic, palmitic, palmitoleic, sapienic, stearic, oleic, vaccenic, linoleic and $\alpha$-linolenic) were first analysed ( $\triangleright$ Fig. 8S ). Subsequently, knowing the molar masses of these fatty acids, and that the macamides are formed through the reaction between the hydroxyl group of the fatty acid and the amino group of the benzylamine [33], we managed to determine the molar masses of the different macamides ( shows the retention times, the $\mathrm{m} / \mathrm{z}$ values of the peaks with greater abundance ( $\vee$ Fig. 2 ), as well as the ion corresponding to each of the macamides present in the sub-fraction IIID ( $\triangleright$ Figs. 4S-7S ).

Through the LC/MS technique, we concluded that sub-fraction IIID is composed of the following macamides: $N$-benzylmyristamide, $N$-benzylpalmitamide, $N$-benzyloleamide and $N$-benzyllinoleamide. We also observed the $N$-benzyloleamide and $N$-benzyllinoleamide macamides are found in greater proportion.

Finally, the fractionation of the sub-fraction IIID by means of a chromatographic column led to the obtaining of 14 sub-fractions, where the IIID2 and IIID4 sub-fractions showed greater activity ( $\triangleright$ Tables 8S-9S). Analysing the IIID2 and IIID4 sub-fractions using ${ }^{1} \mathrm{H}-{ }^{13} \mathrm{C}-\mathrm{NMR}$ and HR-ESIMS techniques, it was established that these sub-fractions corresponded to the $N$-benzyllinoleamide (1) and $N$-benzyloleamide (2) macamides ( $>$ Fig. 3).

To date, macamides were thought to be characteristic marker compounds of Maca hypocotyls (Lepidium meyenii Walp.) [13]. The presence of eighteen macamides have been reported in Maca, among which $N$-benzylpalmitamide is the most abundant compound in the Maca of Peruvian origin, while $N$-benzyllinoleamide is the richest compound in the Maca of Chinese origin (Yunnan) and is the second most abundant compound in the Peruvian Maca [34]. However, the presence of $\mathrm{N}$-oleoyldopamine was recently reported in purple tubers from Mashua (T. tuberosum) of Bolivian origin [24]. In our work we confirm that the yellow tubers from Mashua of Bolivian origin are rich in the $\mathrm{N}$-benzyloleamide and $\mathrm{N}$-benzyllinoleamide macamides; and to a lesser extent in the $N$-benzylmyristamide and $\mathrm{N}$-benzylpalmitamide macamides. We can conclude that these types of compounds may be markers of plant species that grow exposed to extreme climatic conditions (poor soils with a slightly acidic $\mathrm{pH}$ between 5-6 and exposure to ultraviolet radiation at altitudes of 3.800 meters above sea level), consequently producing this type of compounds. The importance of isolating this type of compounds is due to their chemical nature, since they can easily cross the intestinal wall and the blood-brain barrier, exerting a greater pharmacological effect $[13,34]$.

Macamides consist of a residue of a benzylamine (product of the hydrolysis of glucosinolates by the enzyme myrosinase, [35]) and a fatty acid residue (product of the hydrolysis of membrane lipids) that gives it a lipophilic property, a physicochemical parameter that determines the ability of a compound to cross the biological membrane [36]. Therefore, macamides that have a long aliphatic chain can easily cross the cell membrane of cells through diffusion, reaching also the mitochondrial membrane. 
Print Date: 23 May 2017 18:01:02

MS Data Review Active Chromatogram Plot - 23/05/2017 18:00

File: c:|varianws|data|muestras 2017|mayo|sat170157.sms Sample: Sat170157 Operator:

Scan Range: 1 - 11684 Time Range: 0.00 - 66.99 min. Date: 19/05/2017 14:00

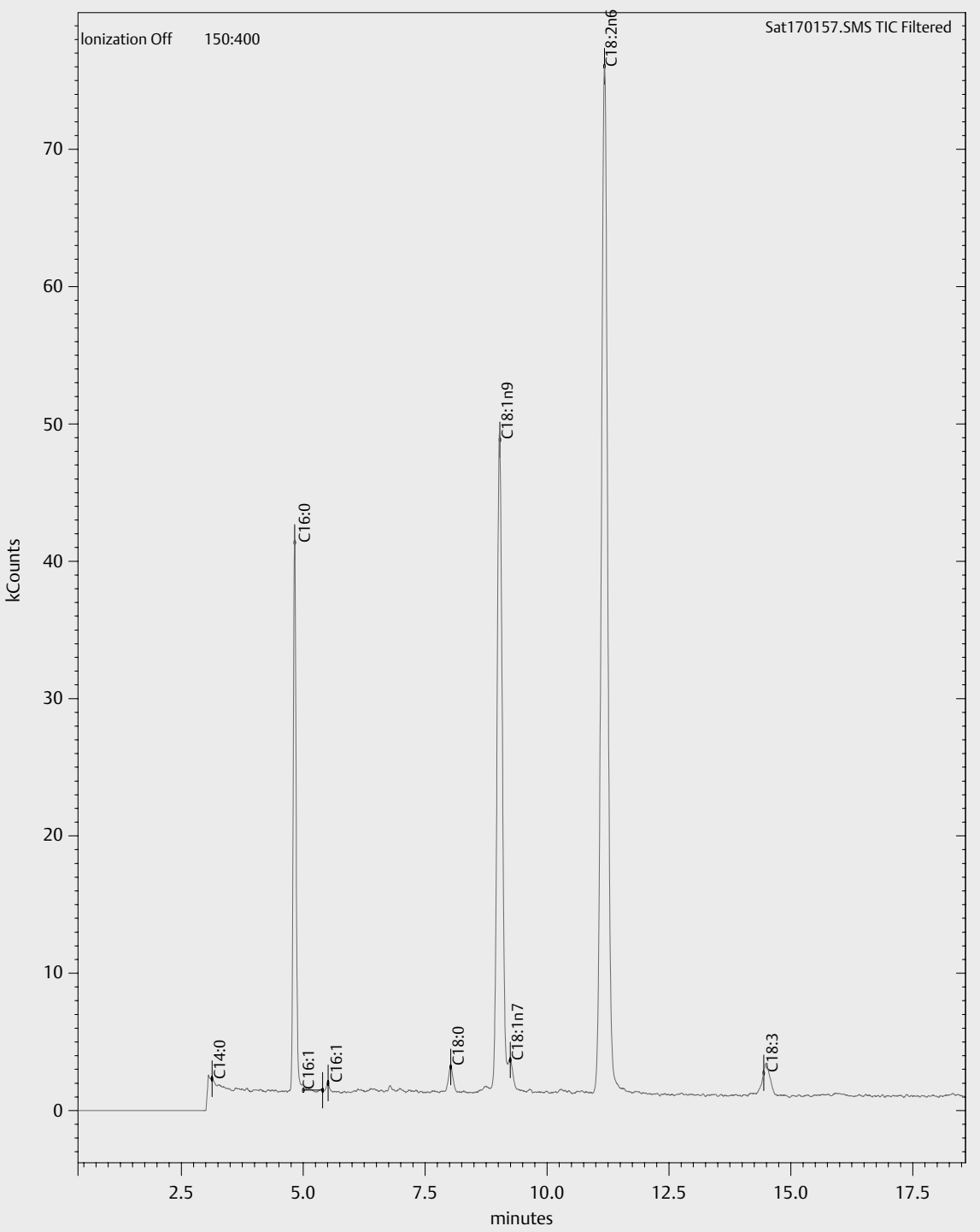

- Fig. 1 GC chromatogram of methyl ester of fraction III of $n$-heptane extract from T. tuberosum.

After the isolation and characterisation of the two macamides present in the $n$-heptane extract from the yellow tubers of $T$. tuberosum, cytotoxicity and viability assays were carried out, comparing them with the Triton X-100 and Actinomycin D controls, respectively.

Compound (1) N-benzyllinoleamide did not show a cytotoxic effect by the LDH assay in CCD-1109Sk, MRC- 5 and RWPE- 1 cell lines with $\mathrm{CC}_{50}$ values of $80.59 \pm 0.90 \mu \mathrm{M} ; 81.42 \pm 0.12 \mu \mathrm{M}$ and $82.79 \pm 0.99$ $\mu \mathrm{M}$, respectively ( $\vee$ Table 6 ). As regard to the control cell line (THP1), the $\mathrm{CC}_{50}$ was $87.00 \pm 0.07 \mu \mathrm{M}$. Regarding the XTT assay, compound (1) had $\mathrm{CC}_{50}$ values of $83.09 \pm 0.53 \mu \mathrm{M} ; 85.09 \pm 0.94 \mu \mathrm{M}$ and
$89.16 \pm 0.57 \mu \mathrm{M}$, respectively ( $\vee$ Table 6), and $89.96 \pm 0.27 \mu \mathrm{M}$ in the control cell line (THP-1).

Regarding compound (2), N-benzyloleamide showed a cytotoxic effect by means of the LDH assay in the CCD-1109Sk, MRC- 5 and RWPE-1 cell lines with $\mathrm{CC}_{50}$ values of $90.62 \pm 0.85 \mu \mathrm{M} ; 94.51 \pm 0.07$ $\mu \mathrm{M}$ and $95.33 \pm 0.97 \mu \mathrm{M}$, respectively ( $\triangleright$ Table 6). Concerning the control cell line (THP-1), the $\mathrm{CC}_{50}$ was $90.67 \pm 0.58 \mu \mathrm{M}$. Regarding the results of the XTT assay, the compound (2) had $\mathrm{CC}_{50}$ values of $94.38 \pm 0.11 \mu \mathrm{M} ; 98.45 \pm 0.62 \mu \mathrm{M}$ and $99.97 \pm 0.39 \mu \mathrm{M}$, respectively ( $\triangleright$ Table 6). It had a $\mathrm{CC}_{50}$ of $92.45 \pm 0.49 \mu \mathrm{M}$ in the control cell line (THP-1). 
To verify the safety of the compounds, the LDH and XTT assays were chosen, which determine the cytotoxicity/viability at different sites of action. More concretely, with the LDH assay we were able to verify the ability of the compounds to penetrate the cell membrane, and with the XTT assay we could verify the ability of

- Table 4 Methyl esters of fatty acids present in fraction III of the $n$-heptane extract from $T$. tuberosum.

\begin{tabular}{|l|l|r|l|l|}
\hline Peak & $\begin{array}{l}\text { Retention } \\
\text { time (min) }\end{array}$ & Peak area & Designation & Fatty acid \\
\hline 1 & 3.137 & 619 & $\mathrm{C} 14: 0$ & Myristic \\
\hline 2 & 4.828 & 128610 & $\mathrm{C} 16: 0$ & Palmitic \\
\hline 3 & 5.398 & 290 & $\mathrm{C} 16: 1$ & Palmitoleic \\
\hline 4 & 5.512 & 1475 & $\mathrm{C} 16: 1$ & Sapienic \\
\hline 5 & 8.028 & 9238 & $\mathrm{C} 18: 0$ & Stearic \\
\hline 6 & 9.033 & 18875 & $\mathrm{C} 18: 1 \mathrm{n} 9$ & Oleic \\
\hline 7 & 9.252 & 3380 & $\mathrm{C} 18: 1 \mathrm{n} 7$ & Vaccenic \\
\hline 8 & 11.184 & 168056 & $\mathrm{C} 18: 2 \mathrm{n} 6$ & Linoleic \\
\hline 9 & 14.444 & 3062 & $\mathrm{C} 18: 3$ & $\alpha$-Linolenic \\
\hline
\end{tabular}

the compounds to act at the level of the mitochondrial membrane [37]. Analysing the results obtained from both the cytotoxicity and viability assays ( $\mathrm{LDH}$ and XTT), we observe that the data for the two compounds are similar to each other and there are no significant differences.

On the contrary, when comparing the results obtained between the compounds, it is evident that compound (1) has a slight cytotoxicity (LDH) and a lower decrease in viability (XTT) with respect to the compound ( 2 ) and this difference can be justified by account-

- Table 5 Retention times with $\mathrm{m} / \mathrm{z}$ of the peaks and the most abundant ions of the macamides present in the subfraction IIID of T. tuberosum.

\begin{tabular}{|l|l|l|l|}
\hline $\begin{array}{l}\text { Retention } \\
\text { time (min) }\end{array}$ & $\begin{array}{l}\text { m/z Peak of } \\
\text { greater } \\
\text { abundance }\end{array}$ & lon & $\begin{array}{l}\text { Corresponding } \\
\text { macamide }\end{array}$ \\
\hline 17.3 & 368.4 & $\mathrm{C}_{25} \mathrm{H}_{38} \mathrm{NO}^{+}$ & $\mathrm{N}$-benzyllinoleamide \\
\hline 19.6 & 318.4 & $\mathrm{C}_{21} \mathrm{H}_{36} \mathrm{NO}^{+}$ & $\mathrm{N}$-benzylmyristamide \\
\hline 20.5 & 344.3 & $\mathrm{C}_{23} \mathrm{H}_{38} \mathrm{NO}^{-}$ & $\mathrm{N}$-benzylpalmitamide \\
\hline 21.7 & 370.4 & $\mathrm{C}_{25} \mathrm{H}_{40} \mathrm{NO}^{-}$ & $\mathrm{N}$-benzyloleamide \\
\hline
\end{tabular}
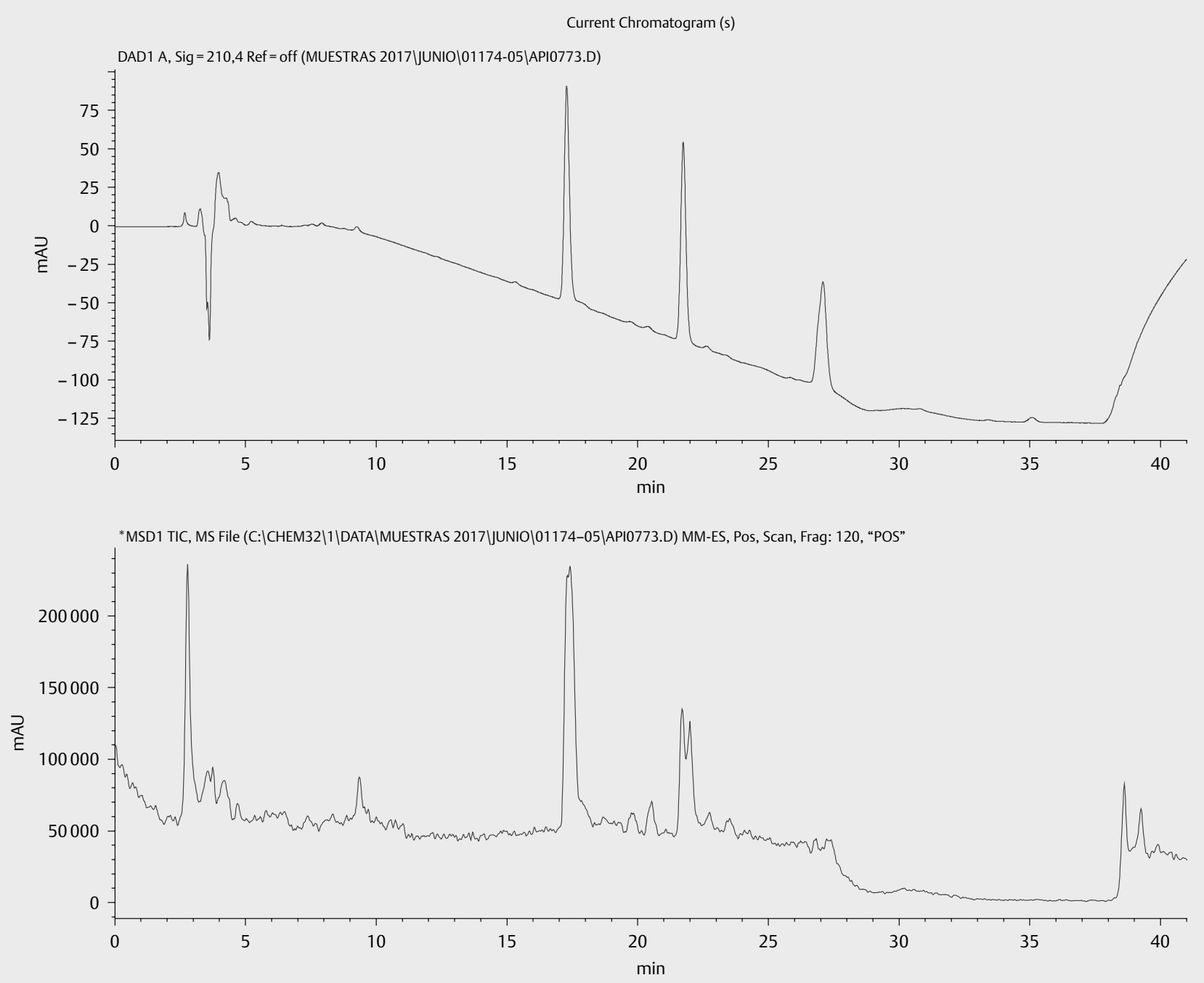

- Fig. 2 Identification of macamides mixture in the HPLC chromatogram of sub-fraction IIID of T. tuberosum. 
ing for the structural differences between these compounds. Compounds (1) and (2) are composed of an unsaturated fatty acid residue (linoleic and oleic), which differs only by the presence of one additional double bond of compound (1) with respect to compound (2). This structural difference in compound (1) would allow it to easily traverse the cell membrane and the mitochondrial membrane, thus justifying the difference in activity [38].

Likewise, the compounds ( $N$-benzyllinoleamide and $N$-benzyloleamide) showed anti-inflammatory activity at $12 \mathrm{~h}$ of treatment in all the cell lines we analysed. With respect to the inhibition of TNF- $\alpha$-induced NF- $\mathrm{KB}$ activation, compounds were compared with respect to the positive Celastrol control $\left(\mathrm{IC}_{50}=7.41 \pm 0.99 \mu \mathrm{M}\right)$. For this assay, Celastrol was chosen, a triterpene used to treat chronic inflammatory and autoimmune diseases. The concentration used in the trials was based on previous research [39].

Compound (1) showed increased activity on CCD-1109Sk $\left(\mathrm{IC}_{50}=2.28 \pm 0.54 \mu \mathrm{M}\right)$; MRC-5 $\left(\mathrm{IC}_{50}=3.66 \pm 0.34 \mu \mathrm{M}\right)$ and RWPE-1 $\left(\mathrm{IC}_{50}=4.48 \pm 0.29 \mu \mathrm{M}\right)$ cell lines with respect to compound (2) with $\mathrm{IC}_{50}$ of $6.50 \pm 0.75 \mu \mathrm{M}$ (CCD-1109Sk); $7.74 \pm 0.19 \mu \mathrm{M}$ (MRC-5) and $8.37 \pm 0.09 \mu \mathrm{M}$ (RWPE-1), respectively. Additionally, compounds (1) and (2) also showed inhibition of TNF- $\alpha$-induced NF-KB activation in control cells (THP-1) with $\mathrm{IC}_{50}$ of $7.13 \pm 0.02 \mu \mathrm{M}$ and $9.78 \pm 0.53 \mu \mathrm{M}$, respectively ( Fig. 4 ).

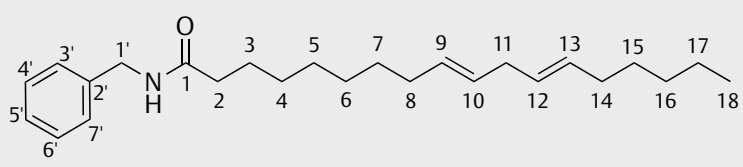

(1)

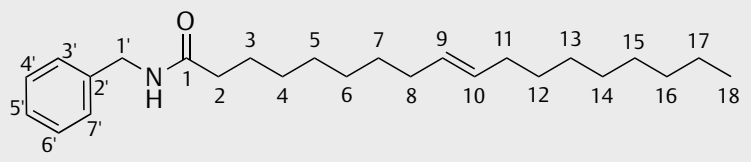

(2)

Fig. 3 Structures of compounds (1) and (2) of the yellow tubers from T. tuberosum.
NF-кB is one of the most important regulators of proinflammatory gene expression. We can indicate through our results that the inhibitory capacity of TNF- $\alpha$-induced NF-KB activation by the macamides ( $N$-benzyllinoleamide and $N$-benzyloleamide) is due to the direct inhibition of I $B$ kinase (IKK $\beta$ ) and to a lesser extent to the IKK $\alpha$ subunits of the $\kappa B$ inhibitor kinase complex $\left(I_{K} B\right)[24,40]$. Our results are comparable to the $N$-oleoyldopamine which was isolated from purple tubers of $T$. tuberosum[24]. This compound showed an inhibition of NF-kB by negative regulation, with an $\mathrm{IC}_{50}$ of 3.54 $\pm 0.02 \mu \mathrm{M}$ in THP-1 cells. However, $N$-benzyllinoleamide (1) and $N$-benzyloleamide (2) showed an $\mathrm{IC}_{50}$ of $7.13 \pm 0.02 \mu \mathrm{M}$ and $9.78 \pm 0.53 \mu \mathrm{M}$, respectively, in the same cell line. This significant difference can be attributed to the presence of the hydroxyl functional groups in the aromatic ring of the $N$-oleoyldopamine. Lastly, the mechanism described above for macamides is similar to the positive control (Celastrol) that blocks IKK activity, nuclear translocation and NF-kB activation [41].

Furthermore, we can indicate that the fatty acid residue (unsaturated fatty acid) present in N-benzyllinoleamide (1) and $\mathrm{N}$-benzyloleamide (2) may be partly responsible for the activity in NF-KB. Indeed, PUFA-derived lipidic mediators, such as eicosanoids or endocannabinoids, can target transcription factors like NF-кB to modulate the gene expression involved in inflammatory disorders $[42,43]$.

Finally, our results show that the isolated compounds also inhibit the activation of STAT3 induced by IFN- $y$, compared to the positive control AG $490\left(\mathrm{IC}_{50}=48 \pm 0.80 \mu \mathrm{M}\right)$. For this assay, compound AG 490 was chosen, an inhibitor of JAKs/STATs pathways with $\mathrm{IC}_{50}$ value of $48 \mu \mathrm{M}$ [44].

Compound (1) showed increased activity on CCD-1109Sk $\left(\mathrm{IC}_{50}=0.61 \pm 0.76 \mu \mathrm{M}\right)$; MRC-5 $\left(\mathrm{IC}_{50}=1.24 \pm 0.05 \mu \mathrm{M}\right)$ and RWPE-1 $\left(\mathrm{IC}_{50}=2.10 \pm 0.12 \mu \mathrm{M}\right)$ cell lines compared to compound $\mathbf{2}$ with $\mathrm{IC}_{50}$ of $5.49 \pm 0.31 \mu \mathrm{M}$ (CCD-1109Sk); $7.73 \pm 0.94 \mu \mathrm{M}$ (MRC-5) and $7.79 \pm 0.30 \mu \mathrm{M}$ (RWPE-1), respectively. Additionally, compounds (1) and (2) also showed inhibition of the activation of STAT3 induced by IFN- $\gamma$ in control cells (THP-1) with $\mathrm{IC}_{50}$ of $6.78 \pm 0.42 \mu \mathrm{M}$ and $9.39 \pm 0.11 \mu \mathrm{M}$, respectively ( Fig. 5).

Inhibition of STAT3 by means of different compounds can take place through different mechanisms such as: phosphorylation, dimerization, transcriptional activity, acting at sites such as JAKs, SH2, DBD [45]. Likewise, there are reports indicating that IFN-y in-

- Table 6 LDH and XTT assays of the compounds from T. tuberosum against a panel of human cell lines after $12 \mathrm{~h}$ of treatment.

\begin{tabular}{|c|c|c|c|c|}
\hline \multirow{2}{*}{ Samples } & \multicolumn{4}{|c|}{ \% Viable cells } \\
\hline & THP-1 & CCD-1109Sk & MRC-5 & RWPE-1 \\
\hline Untreated cells & $99.95 \pm 0.95$ & $99.92 \pm 0.87$ & $98.96 \pm 0.60$ & $99.98 \pm 0.75$ \\
\hline Triton X-100 & $9.37 \pm 0.28$ & $9.18 \pm 0.92$ & $9.29 \pm 0.74$ & $10.44 \pm 0.93$ \\
\hline Compound $\mathbf{1}^{\mathrm{a}}$ & $87.00 \pm 0.07$ & $80.59 \pm 0.90$ & $81.42 \pm 0.12$ & $82.79 \pm 0.99$ \\
\hline Compound $2^{a}$ & $90.67 \pm 0.58$ & $90.62 \pm 0.85$ & $94.51 \pm 0.07$ & $95.33 \pm 0.97$ \\
\hline Untreated cells & $98.95 \pm 0.21$ & $97.97 \pm 0.72$ & $99.91 \pm 0.91$ & $97.96 \pm 0.86$ \\
\hline Actinomycin D & $47.30 \pm 0.31$ & $49.46 \pm 0.88$ & $48.61 \pm 0.12$ & $48.82 \pm 0.27$ \\
\hline Compound $\mathbf{1}^{\mathrm{b}}$ & $89.96 \pm 0.27$ & $83.09 \pm 0.53$ & $85.09 \pm 0.94$ & $89.16 \pm 0.57$ \\
\hline Compound $\mathbf{2}^{\mathrm{b}}$ & $92.45 \pm 0.49$ & $94.38 \pm 0.11$ & $98.45 \pm 0.62$ & $99.97 \pm 0.39$ \\
\hline
\end{tabular}

${ }^{a}$ Cytotoxicity values of the LDH assay. bViability values of the XTT assay. The results are the means $( \pm S D)$ of three separate experiments performed in triplicate. Control $=$ untreated cells. Significant difference among means $(p<0.0001) /$ Tukey's multiple comparisons test. 

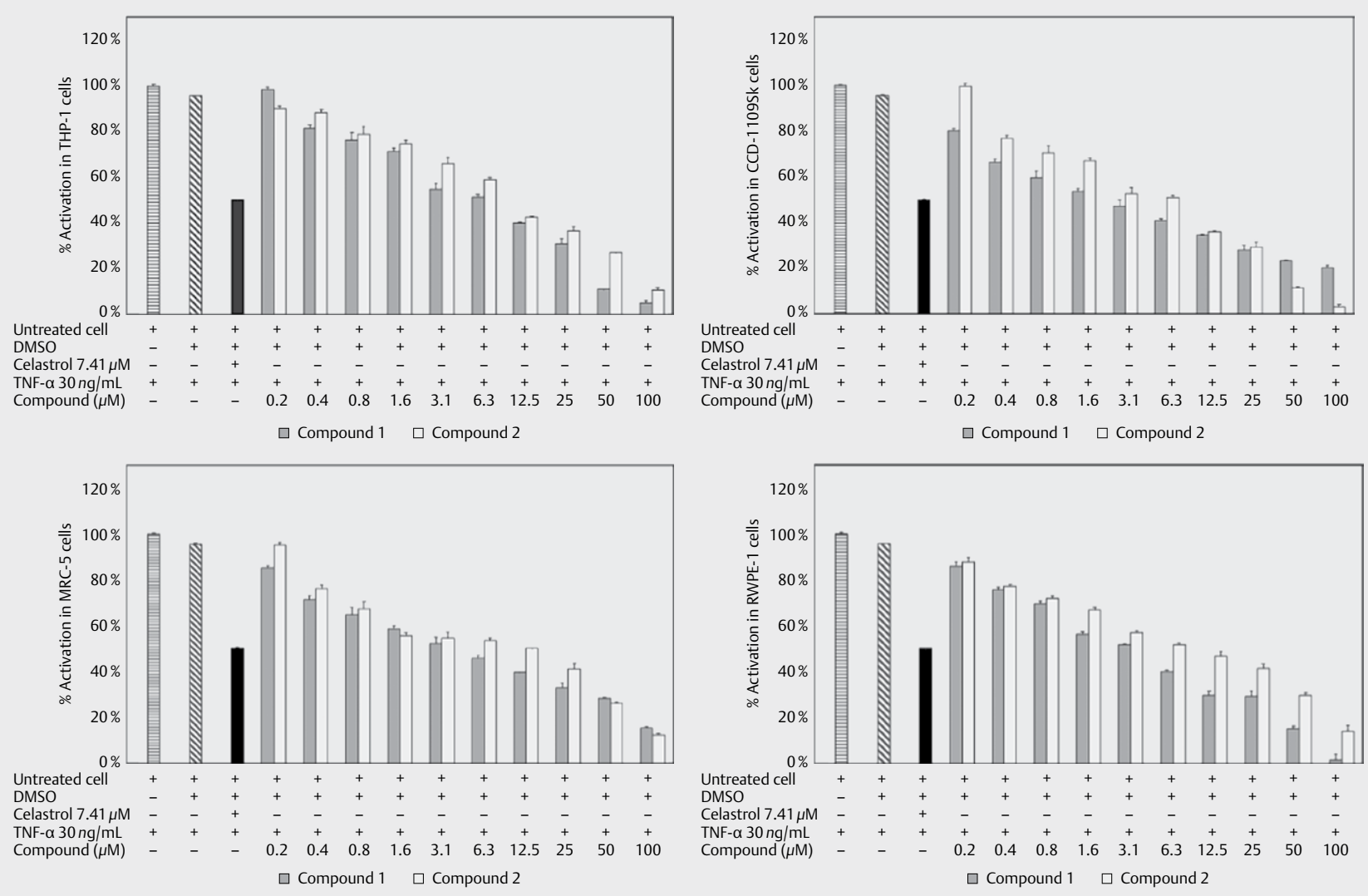

- Fig. 4 Effect of the macamides on TNF- $\alpha$-induced NF-kB activation. Results are represented as the percentage of inhibition considering $100 \%$ the value of TNF- $\alpha$-induced NF-kB activation. The results are the means ( $\pm S D$ ) of three separate experiments performed in triplicate. Control (untreated cells). Significant diff. among means $(P<0.0001) /$ Tukey's multiple comparisons test.

duces the phosphorylation of STAT1, STAT3 and STAT5 through the JAK/STAT signalling pathway [46]. Through our experimental design, we determined that macamides can reduce STAT3 phosphorylation via JAK/STAT caused by IFN-y stimulation, our research being the first report on the activity of macamides on STAT3. The mechanism of action of macamides can be comparable to that of the positive control (AG 490) that inhibits the JAK2, JAK3/STAT, JAK3/AP-1 and JAK3/MAPK pathways [44].

In this case, we can also indicate that the unsaturated fatty acid residue present in $\mathrm{N}$-benzyllinoleamide (1) and $\mathrm{N}$-benzyloleamide (2) may be partly responsible for the activity in STAT3. Mechanistic studies revealed that PUFAs show activity in certain inflammatory disorders that act on JAK-STAT3 signalling [47].

The activity assays of the $N$-benzylmiristamide and $N$-benzylpalmitamide macamides present in the sub-fraction IIID could not be determined because they were in a lower concentration with respect to the $\mathrm{N}$-benzyllinoleamide (1) and $\mathrm{N}$-benzyloleamide (2) macamides. However, if we analyse the fatty acid residue of these macamides we observe that they are saturated fatty acids. Previous studies indicate that unsaturated fatty acids (linoleic and oleic) have a higher anti-inflammatory activity compared to saturated fatty acids (myristic and palmitic) [48].

The importance of the isolation of this type of compounds is due to their chemical nature, since they can easily cross the intes- tinal wall and the blood-brain barrier, exerting a greater pharmacological effect. Taking advantage of this property, there are studies that report the activity of macamides as FAAH inhibitors [49], as neuroprotectors in vitro and in vivo by means of a mechanism mediated by the $\mathrm{CB} 1$ receptor given that they present an analogous structure to endocannabinoidanandamide [50]. In this sense, $\mathrm{N}$ benzyllinoleamide (1) and $\mathrm{N}$-benzyloleamide (2) macamides may have potential therapeutic implications for inflammatory/autoimmune diseases mediated by NF-KB and STAT3.

In conclusion, this study has revealed the identification of four macamides ( $\mathrm{N}$-benzylmiristamide, $\mathrm{N}$-benzylpalmitamide, $\mathrm{N}$-benzyloleamide and $\mathrm{N}$-benzyllinoleamide) for the first time in the yellow tubers of $T$. tuberosum. Furthermore, this work has corroborated that the consumption of cooked tubers of $T$. tuberosum can be a remedy for inflammatory processes of the skin, lungs and prostate.

\section{Material and Methods}

\section{Plant material}

The tubers of T. tuberosum were collected from Titicani-Taca which is located in Villa Asunción de Machaca canton of the Sixth Municipal Section Jesus de Machaca, in the Ingavi province of the La Paz 

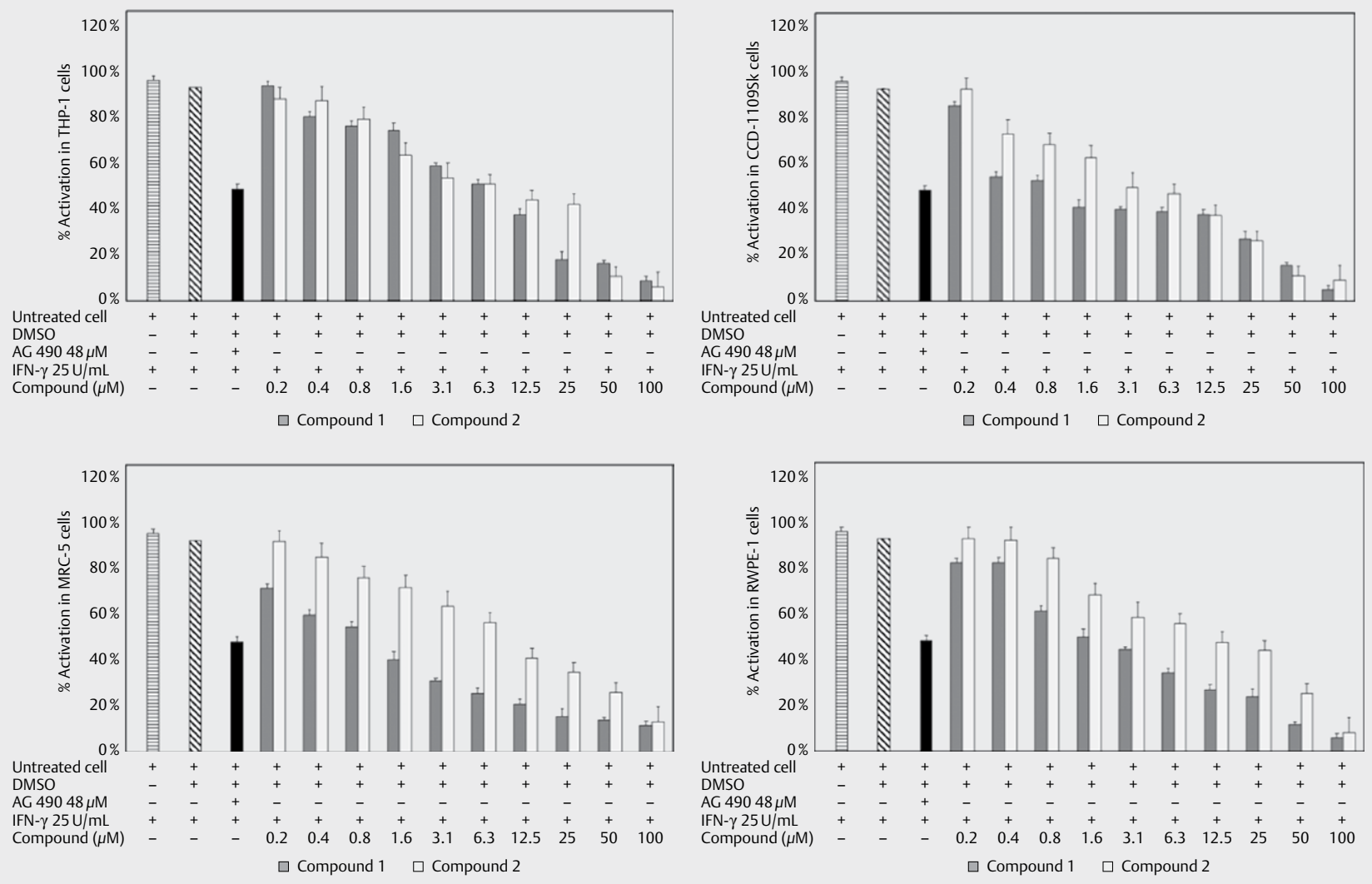

- Fig. 5 Macamides inhibit IFN- $y$-induced STAT3 activation. Results are represented as the percentage of inhibition considering $100 \%$ the value of IFN- $y$-induced STAT3 activation. The results are the means ( \pm SD) of three separate experiments performed in triplicate. Control (untreated cells). Significant diff. among means $(P<0.0001) /$ Tukey's multiple comparisons test.

department, Bolivia ( $16^{\circ} 44^{\prime} 24.5^{\prime \prime}$ S $68^{\circ} 48^{\prime} 49.2^{\prime \prime}$ W), in September 2015, at an altitude of $3900 \mathrm{~m}$. Botanical identification was confirmed by the National Herbarium of Bolivia (No. 14898). Given the fact that yellow tubers are the most consumed Mashua ecotype [13], we have decided to work with this variety of T. tuberosum to confirm its potential as an anti-inflammatory.

\section{General experimental design}

All organic solvents used for isolation and purification were of ACS reagent grade and they were purchased from Sigma-Aldrich. TLC was performed using Merck silica gel $60-\mathrm{F}_{254}$ Plates. Chromatograms obtained were visualised by UV absorbance $(254 \mathrm{~nm})$ and through heating a plate stained with phosphomolybdic acid. Column chromatography was performed with 20-45 $\mu \mathrm{m}$ and 40-63 $\mu$ m silica gel (Merck).

\section{GC/MS analysis}

The determination of FAMEs has been carried out on a Varian 3800 GC chromatograph, with a Varian 4000 MS ion trap detector. A flow of He of $1 \mathrm{~mL} / \mathrm{min}$ and a HP-88 $30 \mathrm{~m} \times 0.25 \mathrm{~mm}(0.2 \mu \mathrm{m})$ were used. The injector temperature was $260^{\circ} \mathrm{C}$, the Split injection mode was $1 / 10$ and the injection volume was $1 \mu \mathrm{L}$. The ionisation mode used was chemical ionisation, with the ionisation gas being $\mathrm{MeOH}$.
In order to carry out the GC/MS analysis of the fatty acids, their methyl esters were prepared. $57.0 \mathrm{mg}$ of the sample with $20 \mathrm{~mL}$ of a solution of $\mathrm{HCl} / \mathrm{MeOH}(162.5 \mathrm{~mL}$ of $6 \mathrm{M} \mathrm{HCl}$ and $137.5 \mathrm{~mL} \mathrm{MeOH}$ ) were introduced into a flask [51]. The mixture was then heated at a temperature of $80^{\circ} \mathrm{C}$, at reflux, for half an hour. After this time, it was allowed to cool until the flask content reached room temperature. Subsequently, successive extractions of the aqueous phase were carried out, with $10 \mathrm{~mL}$ of a mixture of $n$-heptane/diethyl ether (1:1). Finally, the organic phase was washed with $10 \mathrm{~mL}$ of a $1 \% \mathrm{NaOH}$ solution, followed by a wash with $10 \mathrm{~mL}$ of distilled water. After drying the organic phase with anhydrous magnesium sulphate and subsequent filtration, it was concentrated by rota evaporation at a temperature of $40^{\circ} \mathrm{C}$ and an initial pressure of $850 \mathrm{mbar}$ and subsequently a pressure of 120 mbar to obtain $12 \mathrm{mg}$ of a FAMEs mixture.

\section{HPLC and LC/MS analysis}

Macamides were analysed by the HPLC system (2695 pump, 2996 diode array detector; Agilent 1100 Series) coupled with an analytical column 200-C18-48 (4.6x250 mm), with a flow rate of $0.2 \mathrm{~mL}$ / min. The detection wavelength that was used was $210 \mathrm{~nm}$. The mobile phase used was composed of water and $0.1 \% \mathrm{H}-\mathrm{COOH}$ (Phase A) and $\mathrm{CH}_{3} \mathrm{CN}$ (Phase B). Elution was performed in gradient as fol- 
lows: $0-24 \mathrm{~min}, 20-80 \%$; 24-30 $\mathrm{min}, 0-100 \%$; 30-31 min, 20-80\%; and 31-41 min, 20-80\%. The separation temperature was set at $30^{\circ} \mathrm{C}$.

Furthermore, a LC/MS experiment was performed using Agilent Technologies 6120 Quadrupole LC/MS mass detector (Agilent Technologies Inc., Santa Clara, CA, USA). Analytical identification was performed using MRM and ESI in positive mode. The operation conditions were as follows: capillary $2000 \mathrm{~V}$, nebuliser 60 psi, $5 \mathrm{~L} / \mathrm{min}$ dry gas flow rate at $250^{\circ} \mathrm{C}$. Agilent MassHunter Workstation was used for data acquisition and processing.

\section{NMR and MS analysis}

${ }^{1} \mathrm{H}$-NMR spectra were recorded on $300 \mathrm{MHz}$ Bruker Advance DRX instruments. ${ }^{13} \mathrm{C}$-NMR spectra were recorded at $75 \mathrm{MHz}$ on the same instruments. The deuterated solvents were $\mathrm{CDCl}_{3}-d_{1}$; $\mathrm{MeOD}$ $d_{4}$ and $\mathrm{D}_{2} \mathrm{O}$. Spectra were calibrated by assignment of the residual solvent peak to $\delta_{\mathrm{H}} 7.26 ; \delta_{\mathrm{H}} 3.31$ and $\delta_{\mathrm{H}} 4.79$ for $\mathrm{CDCl}_{3}$, MeOD and $\mathrm{D}_{2} \mathrm{O}$, and $\delta_{\mathrm{C}} 77.16$ and $\delta_{\mathrm{C}} 49.00$, for $\mathrm{CDCl}_{3}$ and MeOD. The complete assignment of protons and carbons was done by analysing the correlated ${ }^{1} \mathrm{H}-{ }^{1} \mathrm{H}-\mathrm{COSY}, \mathrm{HSQC}$ and HMBC spectra. Mass spectra were performed on a mass spectrometer with QTOF hybrid model QSTAR pulsar i analyser from the commercial company AB Sciex. The samples were analysed using the electrospray ionisation technique in positive ion detection mode. They were introduced into the mass spectrometer by direct infusion at a flow of $10 \mu \mathrm{L} /$ min using a syringe pump.

\section{Extraction and isolation}

Dried yellow tubers of $T$. tuberosum (300 g) were repeatedly extracted at room temperature with $n$-heptane (7.16 g), $\mathrm{CH}_{2} \mathrm{Cl}_{2}$ / $\mathrm{MeOH}(19.21 \mathrm{~g})$ and distilled water $(4.77 \mathrm{~g})$. Each extract was evaluated for its anti-inflammatory effects in different cell lines, the $n$ heptane extract being more active. Therefore, the $n$-heptane extract was fractionated to identify the active compounds.

The bioactive extract of $n$-heptane $(7 \mathrm{~g})$ was fractionated with $200 \mathrm{~g}$ of silica gel $(40-63 \mu \mathrm{m})$ on a column chromatography $(2 \times 50$ $\mathrm{cm})$, using a gradual gradient of $n$-heptane/AcOEt (20:1), obtaining 9 fractions (I-IX), where fraction III (502.2 mg) showed greater anti-inflammatory activity in all cell lines. Subsequently, fraction III was separated with $15 \mathrm{~g}$ of silica gel $(40-63 \mu \mathrm{m})$ on a column chromatography $(2 \times 50 \mathrm{~cm})$, using a gradual gradient of $n$-heptane/ AcOEt (5:1), obtaining 6 sub-fractions (IIIA-IIIF) that showed antiinflammatory activity in all cell lines tested, sub-fraction IIID (30.36 $\mathrm{mg}$ ) being the most active. Sub-fraction IIID was then separated with $2.5 \mathrm{~g}$ of silica gel $(20-45 \mu \mathrm{m})$ on a chromatography column $(2 \times 50 \mathrm{~cm})$ with $n$-heptane/acetone (7:2) as eluent, obtaining 14 sub-fractions (IIID1-IIID14) with anti-inflammatory activity, the sub-fraction IIID2-compound (1) (1.2 mg) and IIID4-compound (2) $(2.7 \mathrm{mg})$ being the most active.

\section{Cell culture}

Four human cell lines were used in this study: CCD-11095k (Human skin fibroblast, CRL-2361), MRC-5 (Human lung fibroblast, CCL171), RWPE-1 (Human prostate epithelial, CRL-11609) and THP-1 (Human peripheral blood monocyte, TIB-202). All cell lines were obtained from the ATCC. Cells were cultured in specific media ac- cording to ATCC recommendations. The incubation condition for all cells was at an atmosphere of $95 \%$ air and $5 \% \mathrm{CO}_{2}$ at $37^{\circ} \mathrm{C}$.

DMEM (Sigma-Aldrich, St. Louis, MO, USA), FBS (Summit Biotechnology; Ft. Collins, CO) and PBS (SAFC Biosciences, Inc. Andover-Hampshire, UK) were used as culture mediums. L-glutamine was obtained from Applichem. Penicillin and streptomycin were purchased from Fisher Scientific (Pittsburgh, PA). For cytotoxicity and activity assays the compounds were dissolved in DMSO (Merck) at a concentration of $10 \mathrm{mM}$, while extracts and fractions were dissolved at $20 \mathrm{mg} / \mathrm{mL}$ in DMSO.

\section{Cytotoxicity and viability assays}

The cytotoxicity and cell viability of the samples was determined in a panel of three human cell lines (CCD-1109Sk, MRC-5 and RWPE-1) and a control cell line (THP- 1 ) by means of the LDH and XTT assays at different concentrations $(100,50,25,12.5,6.25,3.125,1563$, $0.781,0.391$ and 0.95 ) in $\mu \mathrm{g} / \mathrm{mL}$ (extracts and fractions) or $\mu \mathrm{M}$ (compounds).

LDH assay: The cells were seeded in 96-well plates at a density of $3 \times 10^{3}$ cells/well and incubated overnight at $37^{\circ} \mathrm{C}$ in a humidified atmosphere of $5 \% \mathrm{CO}_{2}$. Subsequently, the cells were treated with the extracts or compounds at different concentrations and using DMSO as a control for $12 \mathrm{~h}$. Triton X-100 (Molecular Biology Grade Sigma-Aldrich, CAS Number 9002-93-1) was used as a positive control at a concentration of $16.51 \mathrm{mM}$, showing cell death. After $12 \mathrm{~h}$ of treatment with the extracts or compounds, $100 \mu \mathrm{L}$ of culture supernatants were collected and incubated in the reaction mixture of the LDH kit (Innoprot Company). After 30 min, the reaction was stopped by the addition of $1 \mathrm{~N} \mathrm{HCl}$, and the absorbance at a wavelength of $490 \mathrm{~nm}$ was measured using a spectrophotometric ELISA plate reader (SpectraMax ${ }^{\circledR}$ i3, Molecular Devices).

XTT assay: The inhibition of $\mathrm{H}_{2} \mathrm{O}_{2}$-induced cytotoxicity by the extracts or compounds at various concentrations was tested by the method of XTT-formazan dye formation [52], using the abovementioned cell lines. These cells were sown $\left(200 \mu \mathrm{L}, 3 \times 10^{3}\right.$ cells/ well) in a 96 -well plate and allowed to grow at $37^{\circ} \mathrm{C}$. After $12 \mathrm{~h}$, medium was removed from all wells. $200 \mu \mathrm{L}$ fresh medium was added to the control wells. Cells in each test well were treated with $0.1 \mathrm{mM}$ $\mathrm{H}_{2} \mathrm{O}_{2}$ (prepared in medium) along with different concentrations of the extracts or compounds. Actinomycin D ( $\geq 95 \%$ Sigma-Aldrich, CAS Number 50-76-0) was used as a positive control at a concentration of $7.97 \mathrm{nM}$, showing cell death. Cells in both control and test wells were re-incubated for $12 \mathrm{~h}$ maintaining the same conditions. After the treatment incubation period, medium in each well was substituted by $200 \mu \mathrm{L}$ of fresh medium, followed by the addition of $50 \mu \mathrm{L}$ of XTT $(0.6 \mathrm{mg} / \mathrm{mL})$ containing $25 \mu \mathrm{M}$ PMS. The plate was further incubated for $4 \mathrm{~h}$ in the same conditions. Absorbance was measured at $450 \mathrm{~nm}$ (with a $630 \mathrm{~nm}$ reference filter) in a spectrophotometric ELISA plate reader (SpectraMax $®$ i3, Molecular Devices, CA, USA).

\section{NF-KB inhibition assay}

All cells were stably transfected with the KBF-Luc plasmid, which contains three copies of NF-KB binding site (from major histocompatibility complex promoter), fused to a minimal simian virus 40 promoter driving the luciferase gene. Cells $\left(3 \times 10^{3}\right.$ for cells/well $)$ 
were seeded the day before the assay on 96-well plate. The cells were then treated with samples (extracts, fractions and compounds) at the same concentrations used in the viability tests for $15 \mathrm{~min}$ and then they were stimulated with $30 \mathrm{ng} / \mathrm{mL}$ TNF- $\alpha$. Celastrol ( $\geq 98 \%$ Sigma-Aldrich, CAS Number 34157-83-0) was used as a positive control at a concentration of $7.41 \mu \mathrm{M}$. After $12 \mathrm{~h}$, the cells were washed twice with PBS and lysed in $50 \mu \mathrm{L}$ lysis buffer containing $25 \mathrm{mM}$ Tris-phosphate ( $\mathrm{pH} 7.8$ ), $8 \mathrm{mM} \mathrm{MgCl}$, $1 \mathrm{mM}$ DTT, $1 \%$ Triton X-100 and $7 \%$ glycerol, during 15 min at room temperature in a horizontal shaker. Luciferase activity was measured using a GloMax 96 microplate luminometer (Promega) following the instructions of the luciferase assay kit (Promega, Madison, WI, USA). The RLU was calculated and the results were expressed as percentage of inhibition of NF-KB activity induced by TNF- $\alpha$ ( $100 \%$ activation). The experiments for each concentration of the test elements were performed in triplicate wells.

\section{STAT3 inhibition assays}

All cells were stably transfected with the $4 x M 67$ pTATA TK-Luc plasmid. Cells $\left(3 \times 10^{3}\right.$ cells/well) were seeded on a 96 -well plate the day before the assay. The cells were then treated for $15 \mathrm{~min}$ with samples (extracts, fractions and compounds) at the same concentrations used in the viability tests, and then stimulated with IFN-y $25 \mathrm{IU} / \mathrm{mL}$. AG 490 ( $\geq 99 \%$ Sigma-Aldrich, CAS Number 133550-30-8) was used as a positive control at a concentration of $48 \mu \mathrm{M}$. After $12 \mathrm{~h}$, the cells were washed twice with PBS and lysed in $50 \mu \mathrm{L}$ lysis buffer containing 25 mM Tris-phosphate (pH 7.8), $8 \mathrm{mM} \mathrm{MgCl}_{2}, 1$ mM DTT, $1 \%$ Triton X-100 and $7 \%$ glycerol, during $15 \mathrm{~min}$ at room temperature in a horizontal shaker. Luciferase activity was measured using the GloMax 96 microplate luminometer (Promega) following the instructions of the luciferase assay kit (Promega, Madison, WI, USA). The RLU was calculated and the results were expressed as percentage of inhibition of STAT3 activity induced by IFN- $\mathrm{\gamma}$ ( $100 \%$ activation). The experiments for each concentration of the test elements were performed in triplicate wells.

\section{Statistical analysis}

The statistical significance of differences was calculated employing the GraphPad Prism software, version 8.2.1 (GraphPad Software Inc., San Diego, CA, USA), using one-way ANOVA followed by Tukey's post hoc test for multiple comparisons. Results were considered different when $p<0.0001$. $I C_{50}$ values were determined by non-linear regression using GraphPad Prism, version 8.2.1. All the experiments were performed in triplicate.

\section{Supporting Information}

Supplementary data (NMR and MS data of compounds) associated with this article can be found in the online version.

\section{Author Contribution}

ARS and MRC contributed to the analysis of the spectral data; LAT and GP contributed to the conception and experimental design of the pharmacological study and LAT contributed to the writing and review of the manuscript.

\section{Funding}

This work was supported by the Fundación de la Universidad Autónoma de Madrid (FUAM).

\section{Conflict of Interest}

The authors declare that they have no conflict of interest.

\section{References}

[1] Hunter P. The inflammation theory of disease. EMBO Rep 2012; 13 : 968-970

[2] Krishnamoorthy S, Honn KV. Inflammation and disease progression. Cancer Metastasis Rev 2006; 25: 481-491

[3] Rumel C. Inflammatory transcription factors as activation markers and functional readouts in immune-to-brain communication. Brain Behav Immun 2016; 54: 1-14

[4] Vallabhapurapu S, Karin M. Regulation and function of NF-kappaB transcription factors in the immune system. Annu Rev Immunol 2009; 27: 693-733

[5] Hayden MS, Ghosh S. Shared principles in NF-kappaB signaling. Cell 2008; 132: 344-362

[6] Levy DE, Lee CK. What does Stat3 do? J Clin Invest 2002; 109: 1143-1148

[7] Herrmann A, Vogt M, Mönnigmann M, Clahsen T, Sommer U, Haan S, Poli V, Heinrich PC, Müller-Newen G. Nucleocytoplasmic shuttling of persistently activated STAT3. J Cell Sci 2007; 120: 3249-3261

[8] Yu H, Pardoll D, Jove R. STATs in cancer inflammation and immunity: A leading role for STAT3. Nat Rev Cancer 2009; 9: 798-809

[9] Yang J, Liao X, Agarwal MK, Barnes L, Auron PE, Stark GR. Unphosphorylated STAT3 accumulates in response to IL-6 and activates transcription by binding to NFkappaB. Genes Dev 2007; 21: 13961408

[10] Fan Y, Mao R, Yang J. NF-KB and STAT3 signaling pathways collaboratively link inflammation to cancer. Protein Cell 2013; 4: 176-185

[11] Bent S. Herbal Medicine in the United States: Review of efficacy, safety, and regulation. J Gen Intern Med 2008; 23: 854-859

[12] Tasneem S, Liu B, Li B, Choudhary MI, Wang W. Molecular pharmacology of inflammation: Medicinal plants as anti-inflammatory agents. Pharmacol Res 2019; 139: 126-140

[13] Apaza TL, Tena VP, Bermejo PB. Local/traditional uses, secondary metabolites and biological activities of Mashua (Tropaeolum tuberosum Ruíz \& Pavón). J Ethnopharmacol 2020; 247: 112152

[14] Fernández HAM, Rodríguez REF. Etnobotánica del Peru Pre-Hispano. $1^{\text {st }}$ Edition. Trujillo: Ediciones Herbarium Truxillense (HUT); 2007: 133-134

[15] De Lucca DM, Zalles AJ. Flora Medicinal Boliviana. $1^{\text {st }}$ Edition. Cochabamba: Los Amigos del Libro; 1992: 401

[16] De Lucca DM, Zalles AJ. Utasan Utjir Qollanaka. Medicinas junto a nuestra casa. $1^{\text {st }}$ Edition. La Paz: Agencia Española de Cooperación Internacional; 2006: 88

[17] Espinosa P, Abad J, Vaca R. Diagnostico de las limitantes de producción y consumo de las raíces y tubérculos andinos en Ecuador. $1^{\text {st }}$ Edition. Ecuador: Instituto Nacional de Investigaciones Agropecuarias (INIAP); 1994 pp. irr

[18] Monteros Altamirano AR. Estudio de la Variación Morfológica e Isoenzimatica de 78 entradas de Mashua (Tropaeolum tuberosum R \& P.). "Santa Catalina"-INIAP [dissertation]. Ecuador: Universidad Central de Ecuador; 1996 
[19] Chirinos R, Campos D, Costa N, Arbizu C, Pedreschi R, Larondelle Y. Phenolic profiles of Andean mashua (Tropaeolum tuberosum Ruiz \& Pavón) tubers: Identification by HPLC-DAD and evaluation of their antioxidant activity. Food Chem 2008; 106: 1285-1298

[20] Chirinos R, Campos D, Arbizu C, Rogez H, Rees JF, Larondelle Y, Noratto G, Cisneros-Zevallos L. Effect of genotype, maturity stage and post-harvest storage on phenolic compounds, carotenoid content and antioxidant capacity, of Andean mashua tubers (Tropaeolum tuberosum Ruiz \& Pavón). J Sci Food Agric 2007; 87: 473-446.

[21] Chirinos R, Campos D, Betalleluz I, Giusti MM, Schartz S], Tian Q, Pedreschi R, Larondelle Y. High performance liquid chromatography with photodiode array detection (HPLC/DAD)/HPLC-Mass spectrometry (MS) profiling of anthocyanins from Andean Mashua tubers (Tropaeolum tuberosum Ruíz \& Pavón) and their contribution to the overall antioxidant activity. J Agr Food Chem 2006; 54: 7089-7097

[22] Martín JC, Ligia HB. Glucosinolate composition of Colombian accessions of Mashua (Tropaeolum tuberosum Ruíz \& Pavón), structural elucidation of the predominant glucosinolate and assessment of its antifungal activity. J Sci Food Agric 2016; 96: 4702-4712

[23] Ramallo RZ. Análisis exploratorio de los ácidos grasos del Isaño (Tropaeolum tuberosum). Investigación \& Desarrollo 2004; 4: 69-74

[24] Apaza TL, Tena VP, Serban AM, Alonso NMJ, Rumbero A. Alkamides from Tropaeolum tuberosum inhibit inflammatory response induced by TNF- $\alpha$ and NF-kB. J Ethnopharmacol 2019; 235: 199-205

[25] White J. Notes on the Biology of Oxalis tuberosa and Tropaeolum tuberosum. Thesis in Biology. Harvard College 1975; 96

[26] Terrazas F, Valdivia F. Spatial dynamics of in situ conservation: handling the genetic diversity of Andean tubers in mosaic systems. Plant Genet Resour Newsl 1998; 114: 9-15

[27] Johns T, Kitts WD, Newsome F, Towers GHN. Anti-reproductive and other medicinal effects of Tropaeolum tuberosum. J Ethnopharmacol 1982; 5: 149-161

[28] García H. Flora medicinal de Colombia. Botánica Médica. Instituto de Ciencias Naturales. Universidad Nacional; Bogotá: 1975: 15-18

[29] Herrera FL. Contribución a la flora del departamento del Cuzco. Perú; Primera parte. Universidad del Cuzco; Cuzco, Perú: 1921

[30] Chan FKM, Moriwaki K, De Rosa M]. Detection of Necrosis by Release of Lactate Dehydrogenase (LDH) Activity. Methods Mol Biol 2013; 979: 65-70

[31] Roehm NW, Rodgers GH, Hatfield SM, Glasebrook AL. An improved colorimetric assay for cell proliferation and viability utilizing the tetrazolium salt XTT. J Immunol Methods 1991; 142: 257-265

[32] de Sousa Andrade IP, Folegatti MV, Almeida Santos ON, Fanaya Junior ED, Barison A, da Conceição Santos AD. Fatty acid composition of Jatropha curcas seeds under different agronomical conditions by means of 1H HR-MAS NMR. Biomass Bioenerg 2017; 101: 30-34

[33] Liu H, Jin W, Fu C, Dai P, Yu Y, Huo Q, Yu L. Discovering anti-osteoporosis constituents of maca (Lepidium meyenii) by combined virtual screening and activity verification. Food Res Int 2015; 77: 215-220

[34] Huang Y], Peng XR, Qiu MH. Progress on the chemical constituents derived from glucosinolates in maca (Lepidium meyenii). Nat Prod Bioprospect 2018; 8: 405-412

[35] Chen J], Gong PF, Liu YL, Liu BY, Eggert D, Guo YH, Zhao MX, Zhao QS, Zhao B. Postharvest ultrasound-assisted freeze-thaw pre-treatment improves the drying efficiency, physicochemical properties, and macamide biosynthesis of maca (Lepidium meyenii). J Food Sci 2018; 83: 966-974
[36] Arnott JA, Planey SL. The influence of lipophilicity in drug discovery and design. Expert Opin Drug Discov 2012; 7: 863-875

[37] Vetten MA, Tlotleng N, Rascher DT, Skepu A, Keter FK, Boodhia K, Koekmoer LA, Andreaos C, Tshikhudo R, Gulumian M. Label-free in vitro toxicity and uptake assessment of citrate stabilised gold nanoparticles in three cell lines. Part Fibre Toxicol 2013; 10: 1-15.

[38] Hawkins RA, Sangster K, Arends M]. Apoptotic death of pancreatic cancer cells induced by polyunsaturated fatty acids varies with double bond number and involves an oxidative mechanism. J Pathol 1998; 185: $61-70$

[39] Nagase M, Oto J, Sugiyama S, Yube K, Takaishi Y, Sakato N. Apoptosis induction in HL-60 cells and inhibition of topoisomerase II by triterpene celastrol. Biosci Biotechnol Biochem 2003; 67: 1883-1887

[40] Sancho R, Calzado MA, Di Marzo V, Appendino G, Muñoz E. Anandamide inhibits nuclear factor- $\mathrm{kB}$ activation through a cannabinoid receptor-independent pathway. Mol Pharmacol 2003; 63: 429-438

[41] Simmonds RE, Foxwell BM. Signalling, inflammation and arthritis: NF-kappaB and its relevance to arthritis and inflammation. Rheumatology 2008; 47: 584-590

[42] Ibrahim A, Mbodji K, Hassan A, Aziz M, Boukhettala N, Coëffier M, Savoye G, Déchelotte P, Marion-Letellier R. Anti-inflammatory and anti-angiogenic effect of long chain n-3 polyunsaturated fatty acids in intestinal microvascular endothelium. Clin Nutr 2011; 30: 678-687

[43] Marion-Letellier R, Savoye G, Ghosh S. Polyunsaturated fatty acids and inflammation. IUBMB Life 2015; 67: 659-667

[44] Mielecki M, Lesyng B. Cinnamic acid derivatives as inhibitors of oncogenic protein kinases-structure, mechanisms and biomedical effects. Curr Med Chem 2016; 23: 954-982

[45] Chen Q, Lv J, Yang W, Xu B, Wang Z, Yu Z, Wu J, Yang Y, Han Y. Targeted inhibition of STAT3 as a potential treatment strategy for atherosclerosis. Theranostics 2019; 9: 6424-6442

[46] Fang P, Hwa V, Rosenfeld RG. Interferon-gamma-induced dephosphorylation of STAT3 and apoptosis are dependent on the mTOR pathway. Exp Cell Res 2006; 312: 1229-1239

[47] Yan D, Yang Q, Shi M, Zhong L, Wu C, Meng T, Yin H, Zhou J. Polyunsaturated fatty acids promote the expansion of myeloid-derived suppressor cells by activating the JAK/STAT3 pathway. Eur I Immunol 2013; 43: 2943-2955

[48] Calder PC, Grimble RF. Polyunsaturated fatty acids, inflammation and immunity. Eur J Clin Nutr 2002; 56: S14-S19

[49] Wu H, Kelley C], Pino-Figueroa A, Vu HD, Maher T]. Macamides and their synthetic analogues: Evaluation of in vitro FAAH inhibition. Bioorg Med Chem 2013; 21: 5188-5197

[50] Gugnani KS, Vu N, Rondón-Ortiz AN, Böhlke M, Maher T], Pino-Figueroa AJ. Neuroprotective activity of macamides on manganese-induced mitochondrial disruption in U-87 MG glioblastoma cells. Toxicol Appl Pharmacol 2018; 340: 67-76

[51] Yang C, Guo ZB, Du ZM, Yang HY, Bi Y], Wang GQ, Tan YF. Cellular fatty acids as chemical markers for differentiation of Acinetobacter baumannii and Acinetobacter calcoaceticus. BES 2012; 56: 5-51

[52] Weislow OS, Kiser R, Fine DL, Bader J, Shoemaker RH, Boyd MR. New soluble-formazan assay for HIV-1 cytopathic effects: application to high-flux screening of synthetic and natural products for AIDS-antiviral activity. JNCl 1989; 81: 577-586 